\title{
TRADITIONALISM IN ARCHITECTURAL EDUCATION
}

\section{EMIL ADAMEC}

Brno University of Technology, Faculty of Architecture, Poříčí 5, 63900 Brno, Czech Republic Tutor: doc. PhDr. Pavel Šopák, Ph.D.

Theme of the dissertation: Traditionalism in Architect Education xaadamece@vutbr.cz

\begin{abstract}
This paper summarizes a current doctoral thesis aiming to analyse the possibilities of applying concepts inspired by traditionalism in the education of $21^{\text {st }}$ century architects, and the theoretical preparation for its implementation in architectural training. The aim is to highlight the theoretical basis supporting the thesis proposal for a studio of traditionalism, which would offer theoretical and practical courses, promote interdisciplinary cooperations, and provide a specific space for this.
\end{abstract}

KEY WORDS: traditionalism, education of architects, alternative digital tools, classical archaeology, passive standards

\section{Introduction}

The fundamental ground of the research is based on a reviewed concept of "traditionalism", and its philosophical direction in the process of supporting architectural education and related holistic learning activities, hence the concept will be explained to clarify the title as a proposed alternative.

\section{Traditionalism}

The term "traditionalism“ is utilised in various fields and interpretations can be confusing. As the foundation for the discussion in this paper, the author adopts Merri- 
am-Webster's general definition of traditionalism as „the beliefs of those who oppose modernism, liberalism, or radicalism". If there were no deliberate rejection of history as hostile as that in $20^{\text {th }}$ century modernism, there would be no need to emphasise „traditionalism“ because building upon past successes had always been preferred. Here it refers to a holistic revival of historically successful architectural heritage, including its theory, approach, style, materials, etc. represented by the Delft School since the end of WWI (Butler, 2010, p. 3).

\section{Current situation}

Aspects involving transmitting knowledge from heritage, interdisciplinary collaboration in practice, as well as curriculum design and the accreditation system are to be explored concerning the presence (including its quantity and quality) of traditionalism in schools. Recent researches based on case studies are reviewed (Mađanovic, 2018, p. 9) (Gournay \& Leconte, 2013, p. 154-198) (Ulusoy \& Kuyrukcu, 2012, p. 2125) (Adamec, 2018, p. 73). According to reports from a EAAE ACE meeting (Spirindonis, Voyatzaki, Maria, \& Meiss, 2010, p. 166), the heads of schools began discussing education issues in 1996, and proposed curricula concerning collaboration with engineering and mathematics over the years without much attention being paid to traditionalism as an option for diversification and specialisation (Asquith \& Vellinga, 2006, p. 3).

The resuscitation of traditionalism as a stylistic alternative in architecture can be observed in the USA, UK, Spain and a few other countries (Kazhar, 2019, p. 11). There are firms specialising in classical, vernacular, or organic architecture beyond modern stylistic options. Organisations such as INTBAU in London,(1) ICAA in New York,(2) and INTSPAC in Hong Kong promote traditionalism in different ways. However, even though a few schools(3) offer traditionalism courses, most students who are seriously considering intensive study and employability would not consider such an option. The claim that students have freedom of style is an illusion due to unbalanced resource allocation based on prevailing modernist preferences and the industry standards which have resulted from this. Along with the pragmatic market monopoly of building materials, digital tools, etc., traditionalism is marginalised in academia and the entire field in general. Modernists argue otherwise (Gelertner, 2020, p. 3) by confusing the teaching of history for historical understanding (Mađanovic, 2018, p. 22) with active teaching for practical application (Mäkelä, 2012, p. 106). Yet when the link between successes, mostly found before the 1920s, and the possible solutions to our current problems is lost, or when inherited knowledge can only be applied in restoration projects, traditionalism is not taught. The curricula of schools in the USA,(4) India(5) and Bhutan(6) show rare exceptions. 

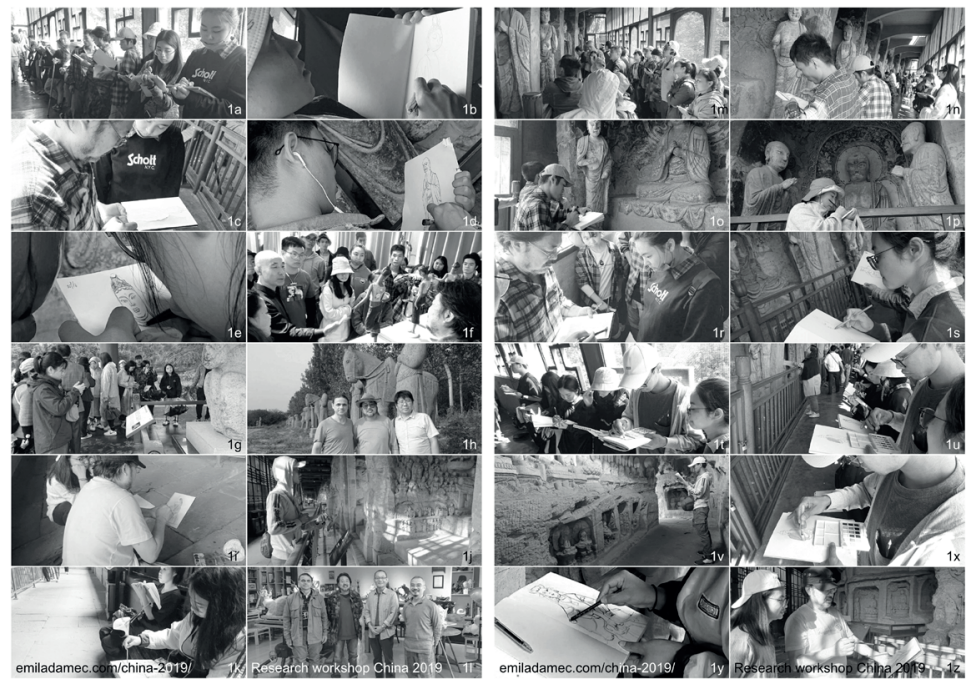

Img. 1. Research workshop China 2019 (Source: E. Adamec).
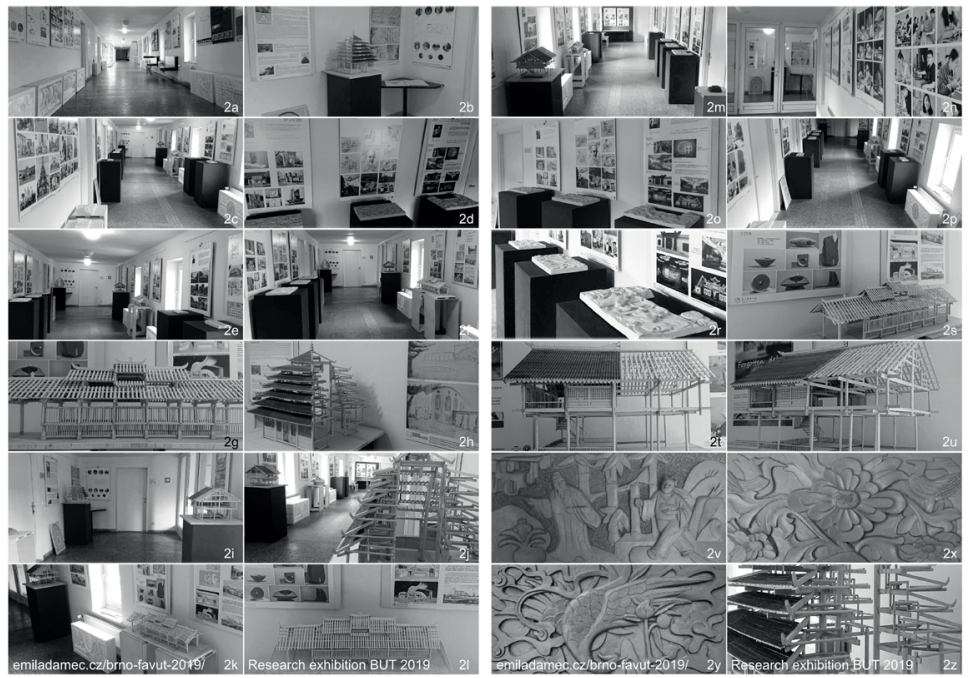

Img. 2. Research exhibition BUT 2019 (Source: E. Adamec).

\section{$21^{\text {st }}$ Century solution}

Chitham summarized the need for future architects to be exposed to classical orders, not as ,a place in the art history curriculum, completely divorced from the practical 
everyday of design", but to equip the next generation of architects with a time-tested body of knowledge to support their core competencies in providing a "passable solution" (Chitham, 2007, pp. 15-16, 18). Practical experience from traditionalism can be readily shared by students from architecture and other artistic disciplines, encouraging collaboration before experimenting with personal vision (and perhaps ego) at the expense of public accountability. Pedagogical reforms have been urged for decades (Salama, 2021, p. 31) without much effective success.(7)

As an alternative solution, this paper proposes to adopt traditionalism by:

$1 /$ extending the compulsory literature to include achievements, especially from the pre-Bauhaus era, in order to promote the assimilation of traditional knowledge towards realistic future application.

$2 /$ connecting the disciplines of art and architecture to ensure architecture students leave their artistic impulses to other artistic professions,(8) rather than fulfilling their aspirations(9) regardless of practical considerations.

3 / incorporating traditionalist knowledge and skills into the accreditation system, in order to recognise students' capability to apply successful pre-Bauhaus knowledge to solve current problems.

\section{Future direction}

The proposed alternative can benefit both teachers and students through choices that were previously not offered. By expanding stylistic options drawing from the past, we may all be better prepared to meet critical sustainability challenges today. To introduce traditionalism comprehensively in the current institutionalised system, the new attempt cannot be merely a part of, or a supplement to, modernist teaching, but must be at least a completely separate discipline. Attempts to mix modernism and traditionalism have always been deemed as a stylistic choice (Mann, 1985, pp. 10-16). The allocation of resources (separate rooms, alternative digital tools, etc) is a prerequisite to allow the new discipline to further develop with reference from classical archeology while meeting latest passive standards..

\section{References}

ADAMEC, Emil, 2018. Traditionalism at Universities, Colleges and in Practice: Urbanism, Architecture, Sculpture, Ornament, Painting and Design. Brno.

ASQUITH, Lindsay, \& VELLINGA, Marcel, 2006. Vernacular architecture in the 21st century: Theory, education and practice. Taylor \& Francis.

BUTLER, Christopher, 2010. Modernism: A Very Short Introduction. OUP Oxford. 
CHITHAM, Robert, 2007. The Classical Orders of Architecture. Routledge.

GELERTNER, Mark, 2020. Making Room for Traditional Architecture. Traditional Building Magazine.

GOURNAY, Isabelle, \& LECONTE, Marie-Laure Crosnier, 2013. American Architecture Students in Belle Epoque Paris: Scholastic Strategies and Achievements at the Ecole des Beaux-Arts. The Journal of the Gilded Age and Progressive Era, 154-198.

KAZHAR, Nina, 2019. Traditions of Classicism in the European Architecture of the XX Century.

MAĐANOVIC, Milica, 2018. Persisting Beaux-Arts Practices in Architectural Education: History and Theory Teaching at the Auckland School of Architecture, 1927-1969. Interstices: Journal of Architecture and Related Arts, 9-24.

MÄKELÄ, T. H., 2012. Why the Classical?: Two decades of teaching at the university of Colorado at Denver: A retrospective glance. The Classicist, 10(2012/2013), 102-107.

MANN, Dennis Alan, 1985. Between Traditionalism and Modernism; Approaches to a Vernacular Architecture. Journal of Architectural Education, 39(2), 10-16.

SALAMA, Ashraf, M., 2021. Transformative pedagogy in architecture and urbanism. Routledge.

SPIRINDONIS, Constantin, VOYATZAKI, Maria, MEISS, Pierre von, 2010. Bologna 10 years after: A critical mapping of the European Higher Architectural Education Area (46). Thessaloniki: European Association for Architectural Education, European Network of Heads of Schools of Architecture.

ULUSOY, Mine, KUYRUKCU, Emine, Yildiz, 2012. The meaning and importance of the traditional architecture in architecture education; Gönen Winter school model. Procedia-Social and Behavioral Sciences, 47, 2120-2126.

\section{Footnotes}

[1] https://www.intbau.org

[2] https://www.classicist.org

[3] https://www.institute-of-traditional-architecture.org/schools/, https://summerschool.premiorafaelmanzano.com

[4] Notre-Dame School of Architecture, USA.

[5] Tamil Nadu Government College of Architecture and Sculpture, India.

[6] College of Science and Technology, Bhutan.

[7] An overview of educators' discussions and actual progress made afterwards, https://www.eaae.be/publications/transactions/

[8] Sculptors, painters, artisans, industrial designers, etc.

[9] e.g. substituting architecture for sculpture and creating architecture as „sculpture“, cf. Gehry, parametric design, various blobs or deconstructions, etc. 